\title{
Fiscal decentralization: the search for new approaches for the development of local government
}

\author{
Natalia Ivanova ${ }^{1}$, Galina Morunova ${ }^{1}$, Vitaliy Fedosov ${ }^{1}$, Svetlana Kuzmina ${ }^{2, *}$ \\ ${ }^{1}$ St.-Petersburg State Economic University, 21, Sadovaya st., 191023 St. Petersburg, Russia \\ ${ }^{2}$ St.-Petersburg State Institute of Film and Television, 13, Pravda st., 191119 St.-Petersburg, Russia
}

\begin{abstract}
In this article, the authors consider issues of fiscal decentralization in the context of sustainable development of territories, justify the development trends of the world community in providing public goods for the population. The analysis of this issues is carried out in comparison of indicators for Russia and the countries of the Organization for Economic Cooperation and Development (OECD). This allows assessing the current level of fiscal decentralization in the world community, in Russia, and also determining its prospects. The authors presented the results of the study, which contain the dynamics of subnational budgets of Russia and OECD countries, separately identified local budgets, the dynamics of financing of proactive budgeting, the typology of the main projects of proactive budgeting, examples of municipal-private partnership projects implemented in Russia. In addition, the article sets out new approaches to the financial support of local government activities in the country, based on the introduction of selftaxation, bond loans and other forms of financing at the municipal level.
\end{abstract}

\section{Introduction}

The scientific view of the modern role of local government as a democratic institution, which is also responsible for effective political exchange in society, changes the role of municipal finances. They become not only the economic basis of local government, but also the material basis of political exchange between the state and the population («statepopulation» exchange). In accordance with the approaches of representatives of the theory of fiscal federalism, the federal government is responsible for macroeconomic stability and redistribution of income. The authorities at the subfederal and especially at the municipal level, having information about the preferences of citizens, perform an important allocation function - ensuring the efficiency of public goods in their territories (maximum satisfaction of the needs (interests) of the local population at the lowest cost). Fiscal decentralization, contributing to the public finances implementation of the allocation function, ultimately stimulates economic growth in the country; therefore, there is a clear trend in the world community towards an increase in fiscal decentralization. However, in Russia over the past

\footnotetext{
*Corresponding author: kuzmina2003@bk.ru
} 
ten years, the opposite trend has been observed (especially at the municipal level), which in the end can have a negative impact on economic growth and reduce the sustainable development of territories. New approaches to decentralization at the municipal level, associated with the use of self-taxation of citizens, municipal-private partnerships, proactive budgeting, the introduction of municipal bond loans, etc., will contribute to the development of municipal and public finance, as well as strengthen local government in Russia, increase satisfaction population that will positively affect the political exchange «state-population».

\section{Materials and Methods}

Since the end of the last century, issues of fiscal decentralization and its impact on economic development have been actively discussed by the foreign scientific community, for example, the following questions are reflected in scientific publications: income redistribution - Garcia-Mila, Teresa; McGuire, Therese J.; Oates, Wallace E., 2018[1], Zimmermann H., 2004 [2]; models of the possible impact of fiscal decentralization on economic growth - Davoodi, Zou, 1998 [3], Freinkman, Lev and Kholodilin, Konstantin A. and Thiessen, Ulrich, 2009 [4]; the correspondence between expenditures and own revenues of subnational authorities - Gemmell, Norman and Kneller, Richard and McGowan, Danny and Sanz, Ismael and Sanz-Sanz, José F 2013 [5] and others.

Russian studies present such issues as: the impact of fiscal decentralization on the balance of budgets; the impact of fiscal decentralization on the efficiency of budget expenditures-study of the expert working group "Optimization of budget expenditures in the field of public administration" to assess the effectiveness of Federal budget expenditures and the formation of proposals for their optimization in 2013, carried out by the Russian Academy of national economy and public service and the Higher school of Economics together with the Ministry of Finance, the Ministry of economic development of Russia and other interested Federal Executive bodies - Yuzhakov, V.N., Dobrolyubova, E.I., Pokida, A.N., Zybunovskaya, N.V. [6], 2019; the relationship of fiscal decentralization with allocational and production efficiency - research of the international center for socioeconomic research "Leontief center", - Yushkov A.O., Oding N.Y., Savulkin L.I., 2018 [7]; the impact of the imbalance of the budget system of Russia on the economic inequality of territories - N. M.Sabitova, N.G.Ivanova 2016 [8] ; public participation of citizens in the budget process - Fedosov, 2017 [9]; sustainable development of municipal finance G.V.Morunova, 2018 [10,11], assessment of the quality of life and sustainable development of communities, development of standards in the field of sustainable development, indicators for monitoring the quality of life - V.V.Okrepilov, S.N.Kuzmina. [10, 12].

The authors summarize huge material on fiscal decentralization of the Russian Federation and OECD members using mathematical and statistical data processing methods. General government includes four sub-sectors: central/federal government and related public entities; federated government ("states") and related public entities; local government i.e. regional and local governments and related public entities and social security funds. Data are consolidated within general government as well as within each subsector (neutralization of financial cross-flows). Subnational government is defined here as the sum (non-consolidated) of federated government and local government.

The theory of the budgetary federalism allocates three main functions of the public sector: 1) achievement of macroeconomic stability; 2) redistribution of income; 3) increase in cost efficiency (allocation function).

Allocation function is investigated by foreign and Russian authors by consideration of the fiscal decentralization which is one of conditions of the budgetary federalism. We will understand the fiscal decentralization as process of distribution of the budgetary powers in 
the direction of subnational authorities. The most general indicators of the fiscal decentralization, according to authors, are: specific weight (share) of income and expenses of subnational budgets respectively in income and expenses of the budget of «general government» (The budget of "general government" is set of all budgets which are a part of the budgetary system of the country including budgets of state non-budgetary funds); specific weight (share) of the inter-budget transfers in income of subnational budgets. The structure of the fiscal decentralization can be expanded as it will be shown further.

Theoretical argument in favor of the fiscal decentralization is the possible allocation and production efficiency of granting public benefits, i.e. the subordinate authorities, knowing needs of citizens, can satisfy individual requirements (allocation efficiency) with lower expenses (production efficiency) more fully. Identification of communication between the fiscal decentralization and economic growth is the popular direction of modern researches. However so far results of researches are contradictory and depend on the applied methodology, the used definitions of decentralization and its indicators [7].

At the same time, researches showed that stationary values of economic growth depend on shares of various levels of management in the total amount of the budgetary expenses (account decentralization). In general the hypothesis is confirmed: achievement of balance between income and expenses at the lower levels of management is positively connected with growth of economy and also promotes creation at the subnational authorities of incentives to protection of market institutes. In case of excess of expenses over income the positive interrelation between decentralization of income and economic growth, and negative communication between decentralization of expenses and growth is observed. Conditions of effective decentralization were as a result formulated: compliance between expenses and own revenues of the subnational authorities; transparency of the budgetary procedures, autonomy of regions and municipalities, the functioning market institutes; the steady system of the interbudgetary transfers - tight budgetary restrictions, adequate formulas of distribution, balance between grants and subsidies [7].

Our calculations show that the level of decentralization of income of subnational budgets in the Russian Federation following the results of 2016 was 35.2\% that below average value over the countries of OECD $-42.4 \%$ (Fig. 1).

It is necessary to consider that the majority of the countries of OECD are unitary states. Part of them has very centralized budgetary system. The average indicator of decentralization of income of subnational budgets in federal states of OECD is $53.1 \%$. Therefore if to carry out comparison only with federal states of OECD, then Russia concedes to all on the level of decentralization of income of subnational budgets.

In general in the countries of OECD the tendency to increase in decentralization of the budgetary systems is observed, but it can be reached as by means of increase in a tax and non-tax income of subnational budgets, and at the expense of transfers from the central budget. There is a steady opinion that in the Russian Federation the large volume of transfers is provided from the federal budget to budgets of territorial subjects of the Russian Federation, as allows to reach a moderate indicator of decentralization of income of the budgetary system. As it is possible to see from figure 1, the share of transfers to budgets of territorial subjects of the Russian Federation in 2016 made only 9.2\% in structure of their income while on average in OECD this indicator equals $37.2 \%$ of the federal budget. If to take into account that in the unitary states at more centralized budgetary system the bigger amount of money which come then to local budgets is redistributed through the central budget, then even comparison with federal states in which the share of transfers in income of subnational budgets averages $31.5 \%$, speaks about the low level of financial support of territorial subjects of the Russian Federation from the federal budget. 


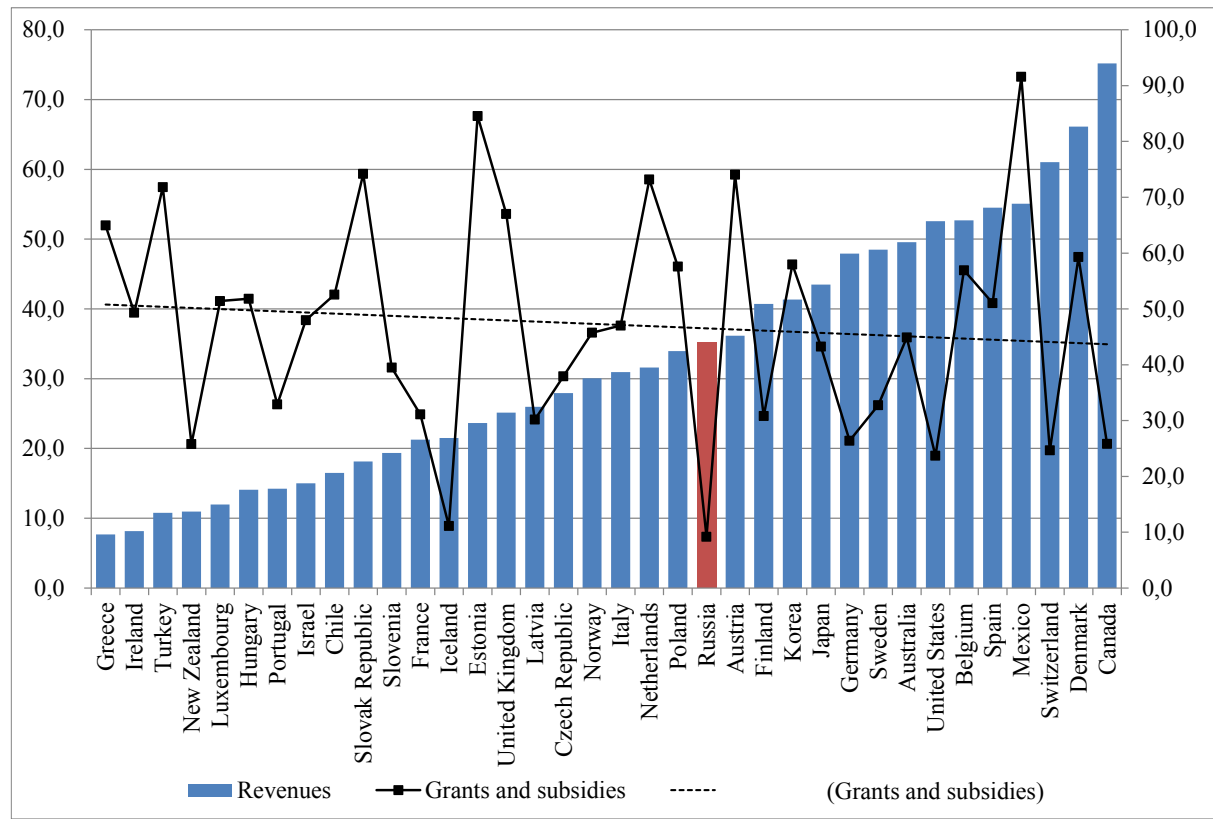

Fig. 1. Fiscal decentralization on income of subnational budgets of the countries of OECD and the Russian Federation in 2016, \% (made by authors according to OECD and Federal Treasury data).

Where by the sphere of income of the Russian Federation has following identifying features:

- high level of the oil and gas revenues coming to the federal budget. The external economic environment essentially affects the size of oil and gas revenues of the federal budget, but their share decreases not only because of drop in oil prices in recent years, but also because of implementation of the "tax maneuver" setting as the purpose to replace the export customs duties on oil with a severance tax and also thanks to introduction of "the budgetary rule" which reduces dependence of federal revenues on fluctuations of the world prices for energy carriers;

- considerable differentiation in development of regions of the Russian Federation that causes essential differences in the level of fiscal capacity of subnational budgets and need of granting grants for their alignment. Despite rather high differentiation of budget revenues counting on 1 inhabitant on territorial subjects of the Russian Federation, differences between regions were reduced from 73 times in 2000 to 15 times in 2015, and the coefficient of a variation of budget revenues counting on 1 person decreased almost by 3 times. These changes happened against the background of decrease in a share of the interbudgetary transfers in expenses of the federal budget and practically against the background of their invariable share in income of the consolidated budgets of territorial subjects of the Russian Federation [13].

It is important to distinguish political decentralization (higher in federal states) and the fiscal decentralization which can be high or low regardless of type of the state [13, page 16]. The form of government (confederation, federation, unitary) influences decentralization of income, but is not the defining factor. In particular, the level of decentralization of budget revenues in unitary Denmark and Sweden is higher, than in federal Germany and Austria.

Decentralization on expenses of subnational budgets of the countries of OECD and the Russian Federation in 2016 corresponds to the fiscal decentralization on income taking into account the interbudgetary transfers (Fig. 2). 


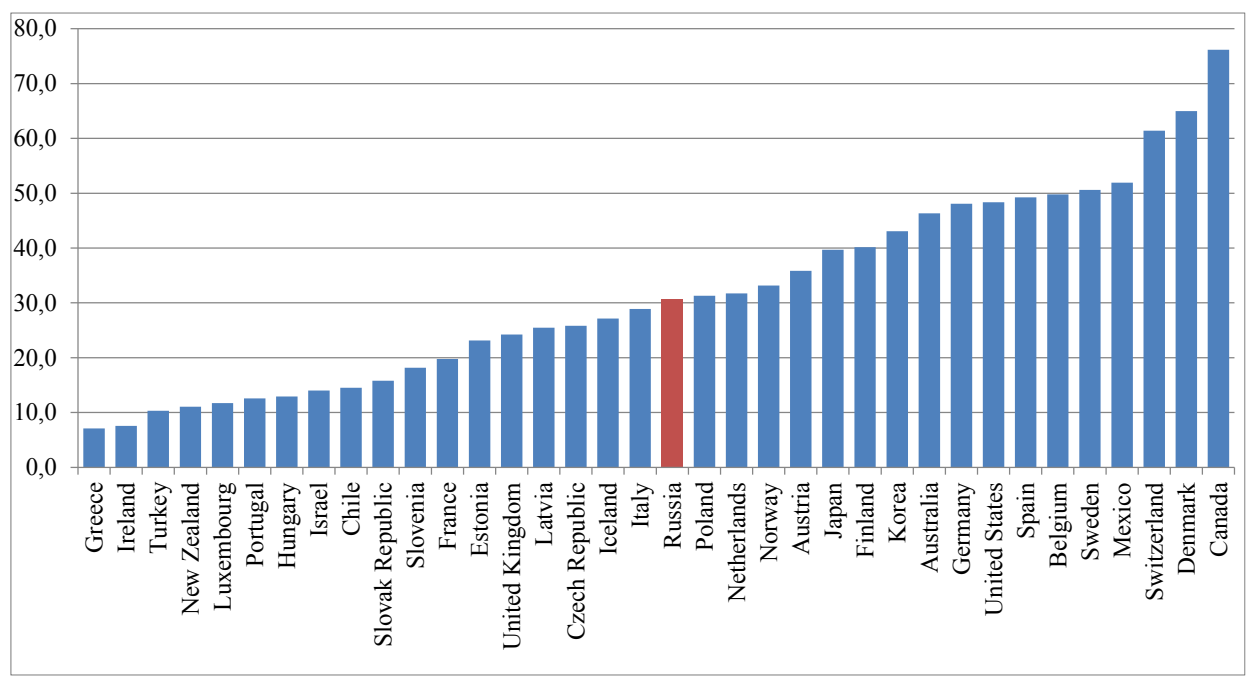

Fig. 2. Fiscal decentralization on expenses of subnational budgets of the countries of OECD and the Russian Federation in 2016, \% (made by authors according to OECD and Federal Treasury data).

On the level of the fiscal decentralization on expenses the Russian Federation takes lower place among the countries of OECD with an indicator in $30.7 \%$. It is caused by the following factors:

- lower level of the interbudgetary transfers from the federal budget to budgets of territorial subjects of the Russian Federation for comparison with the countries of OECD;

- essential budget deficit of the general government.

Crisis of sovereign debts in 2009-2014 led to revision of the budgetary policy not only on state, but also at the subnational level in the countries of OECD. Effective management of debt obligations of regional and local authorities allows these public educations to realize the account obligations. Therefore the analysis of subnational debts is also an important element in a research of the fiscal decentralization. Subnational debts of the countries of OECD and the Russian Federation for 2016 are presented in Fig. 3. 


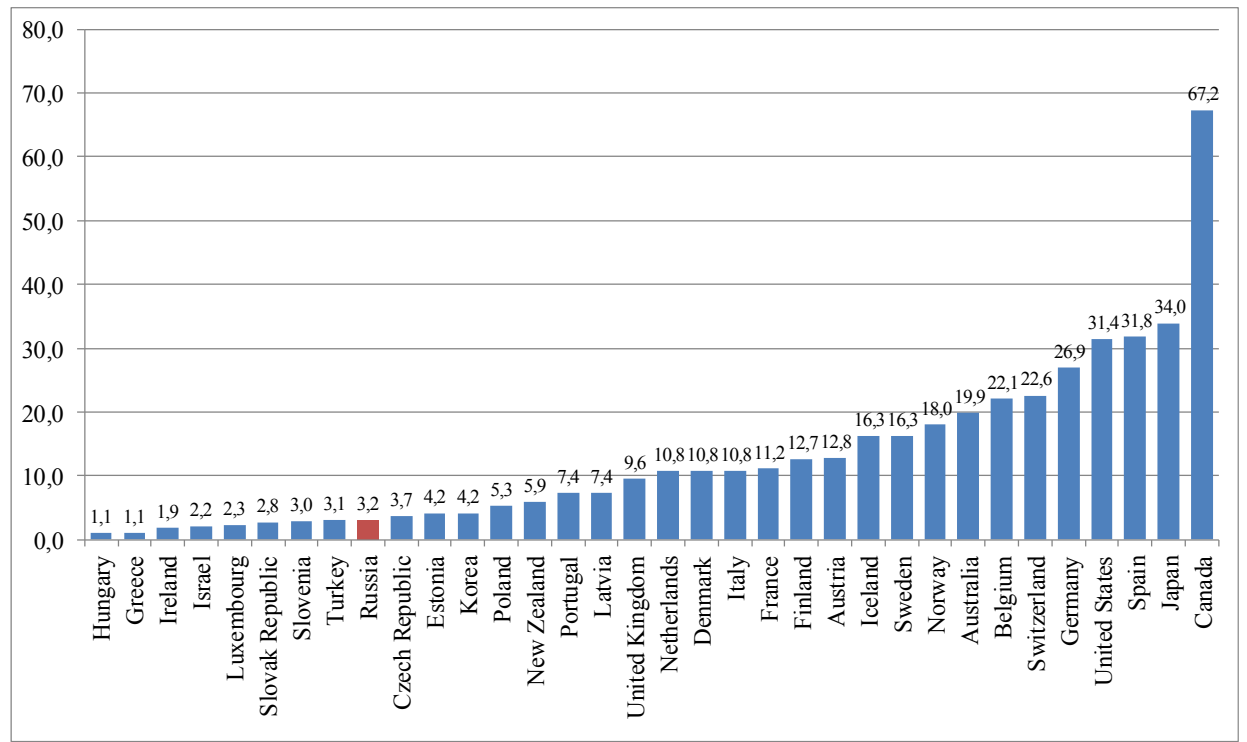

Fig. 3. Subnational debts of the countries of OECD and the Russian Federation for 2016, GDP \% (According to OECD, the Ministry of Finance of the Russian Federation (the indicator across Mexico and Chile is absent).

Despite vital issues at certain regions and municipal units, the level of debt obligations in relation to GDP in the Russian Federation in 2016 was 3.2\%. Average value of a similar indicator over the countries of OECD is $24.5 \%$ that is explained by the high level of subnational debts in large economies of such countries as Germany, the USA, Spain, Japan and Canada.

Russia is the federal state where the local government is proclaimed at the constitutional level therefore separate studying of local budgets (besides a research of subnational budgets) is of interest in the analysis of the fiscal decentralization. The share of income of local budgets in the budgetary system of the Russian Federation made 12.9\% in 2016 that below as average value over the countries of OECD in general $-14.0 \%$, and average value on federal states of OECD - 18.3\% (Fig. 4). 


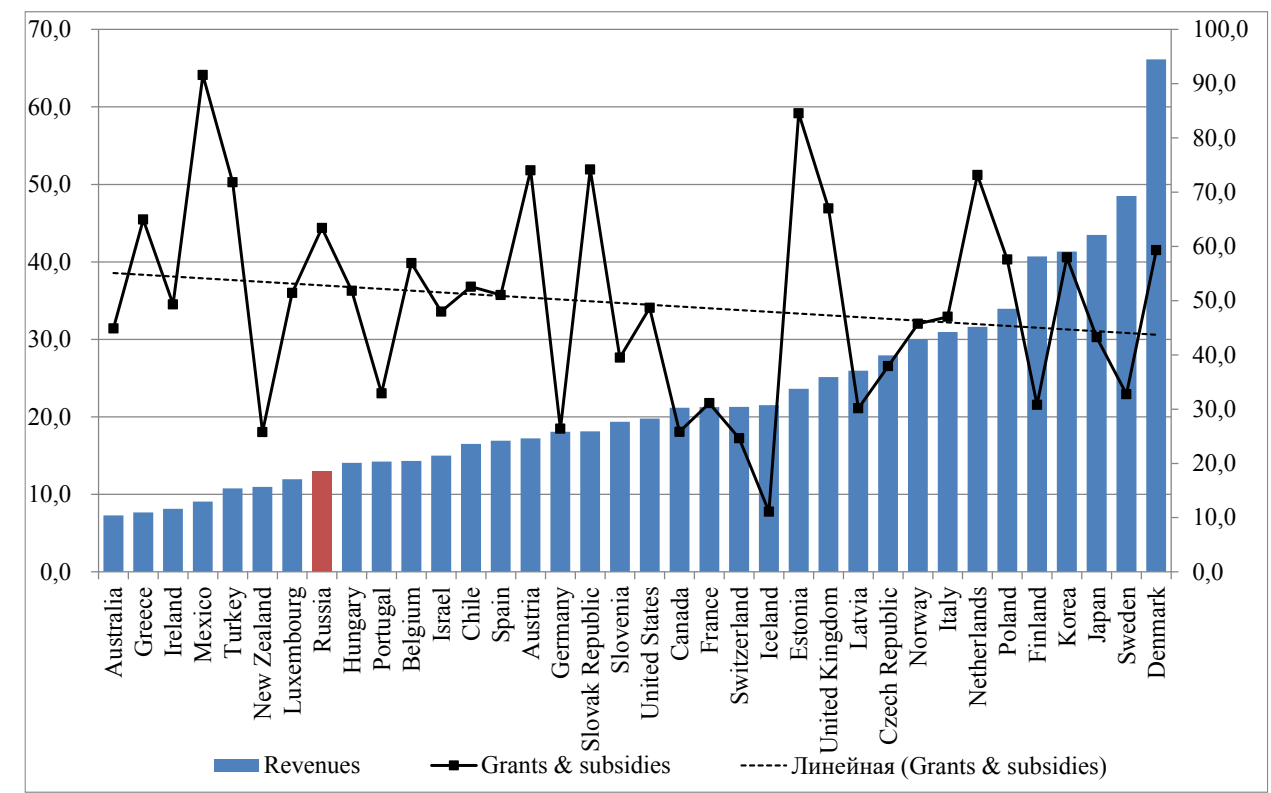

Fig. 4. The fiscal decentralization of income of local budgets of the countries of OECD and the Russian Federation in 2016, \% (made by authors according to OECD and Federal Treasury data).

The analysis of the fiscal decentralization on income of local budgets of the countries of OECD and the Russian Federation for 2016 allows to draw the following conclusions:

1. higher specific weight of income of local budgets in income of the consolidated budgets of these countries is observed in the unitary states.

2. At the local level, also as well as on subnational, the correlation between decentralization of budgets and shares of the interbudgetary transfers in local budgets is not observed. However with increase in income the share of the interbudgetary transfers decreases that is shown by a linear curve of a trend.

3. There are various approaches to formation of income of budgets of municipal units therefore for them can be characteristic: prevalence in budgets of local taxes; transfer in local budgets of a part of income from federal and regional (state) taxes; prevalence in budgets of the interbudgetary transfers from higher budgets. Unlike the regional level, the dependence of local budgets of the Russian Federation on higher budgets is considerable in $201663.4 \%$ of income of local budgets were the interbudgetary transfers of regional budgets with an average over the countries of OECD - 37.2\% (on federal states $-31.5 \%$ ). At the same time the most essential tax source of local budgets is the income tax (personal income tax), federal on the status. This situation allows to speak about a small part of own local income (tax and non-tax) in implementation of the budgetary policy of municipalities.

In Switzerland and Canada, for example, the share of the interbudgetary transfers in revenue breakdown of local budgets made about $25 \%$ at the high specific weight of income of local budgets in the budgetary system. Presence of stable tax base at municipalities in total with the low level of financial aid from higher budgets allows municipalities to realize long-term budgetary policy in these countries and in its framework effectively to interact with citizens. There is other polar example among federal states. So, in Mexico the share of income of local budgets in the consolidated budget of the country made $9.1 \%$ following the results of $2016.91 .6 \%$ arrived in the form of the interbudgetary transfers from the total amount of income of local budgets.

Let's carry out the analysis of the fiscal decentralization at the level of local budgets in the Russian Federation for income (Fig. 5). 


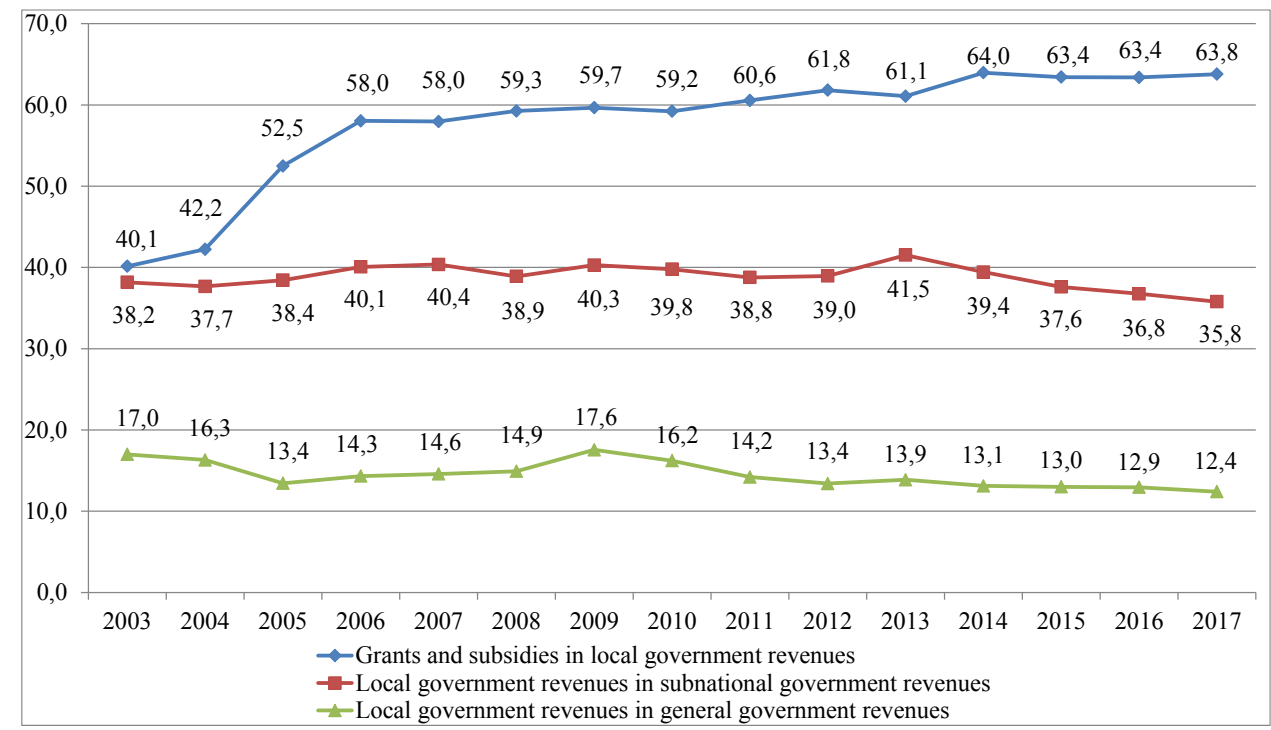

Fig. 5. The fiscal decentralization on income of local budgets in the Russian Federation for 20032017, \% (made by authors according to OECD and Federal Treasury data).

Reform of local government in the Russian Federation started in 2003 with adoption of Federal law No. 131-FZ "About the general principles of the organization of local government in the Russian Federation" [14]. Territorial subjects of the Russian Federation had to create new structure of municipal units and local budgets from 2006 for 2009.

As it is possible to see from Fig. 5, the share of income of local budgets in revenue breakdown of the budgetary system of the Russian Federation in 2005 was sharply reduced, and the specific weight of the interbudgetary transfers in income of local budgets increased in 2005 up to $52.5 \%$, and in 2006 - up to $58.0 \%$. The decision of federal authorities to redistribute transfer of income tax between budgets of the budgetary system of the Russian Federation became the main reason for such significant changes. Income tax till 2005 came to local budgets for the standard of 2\%, since January 1, 2005 it began to be enlisted only in the federal budget and budgets of territorial subjects of the Russian Federation.

"Spurts" in income of local budgets for the considered period are connected with the following factors:

- in 2006 (growth by 0.9 items) reform of local government really began that is connected, first of all, with increase in number of local budgets more than by 1.7 times in comparison with 2005 ;

- $\quad$ in 2009 (growth by 2.7 items) there was a fall of federal revenues and budgets of territorial subjects of the Russian Federation because of an economic crisis, at the same time volumes of income of local budgets remained at the pre-crisis level.

After adoption of the decrees of the President of the Russian Federation in May, 2012 providing new account obligations, the considerable burden on their financing was assigned to local budgets. However they could not fulfill in full the account obligations, and since 2014 financing of the main educational programs at schools was assigned to territorial subjects of the Russian Federation with transfer of 5\% of a personal income tax from municipal on the regional level. Since then some more decisions at the federal and regional levels which led to centralization of the budgetary system that affected indicators of local budgets were accepted. During 2014-2017 the share of income of local budgets in the budgetary system of the Russian Federation was reduced by 1.5 items, in the consolidated 
budgets territorial subjects of the Russian Federation - by 5.7 items, and the share of the interbudgetary transfers grew by 2.7 items, having reached $63.8 \%$. The fiscal decentralization on expenses of local budgets in the Russian Federation for 2003-2017 is presented in Fig. 6.

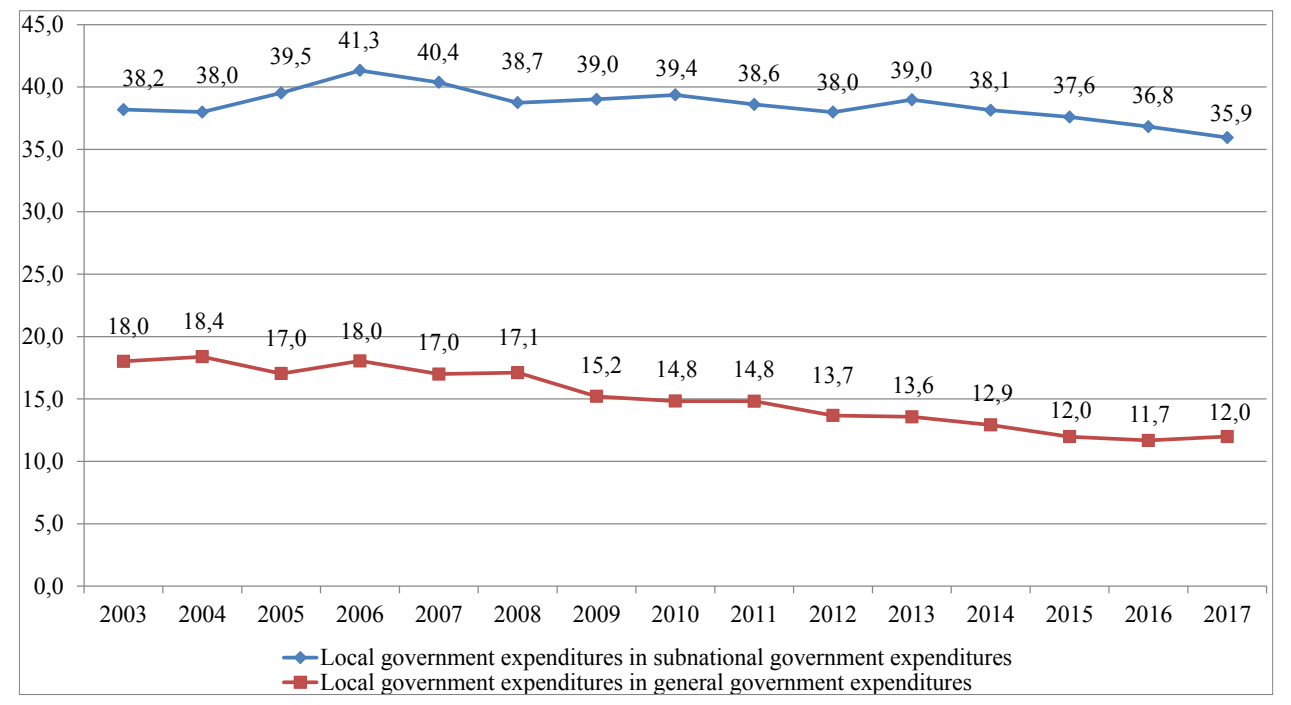

Fig. 6. The fiscal decentralization on expenses of local budgets in the Russian Federation for 20032017, \% (made by authors according to OECD and Federal Treasury data).

Since 2006 the fiscal decentralization on expenses of local budgets in the Russian Federation has a steady tendency to decrease and by 2017 reached $12 \%$ in income of the budgetary system of the Russian Federation and 35.9\% in income of the consolidated budgets of territorial subjects of the Russian Federation. This trend is characteristic also of the fiscal decentralization on income, i.e. at the municipal level we observe reduction of the fiscal decentralization.

\section{Results}

Researches showed that in the countries of OECD growth of the fiscal decentralization is observed, but in the Russian Federation there is a gradual centralization of the budgetary system, i.e. the fiscal decentralization both on income and on expenses decreases both at the subfederal level, and on municipal. This situation was aggravated with the fact that during 2014-2017 federal public authorities assigned to territorial subjects of the Russian Federation of power on execution of account obligations of municipalities, or territorial subjects of the Russian Federation were forced "to take away" separate powers of municipal units as the last had no financial opportunity to execute them. Not only deterioration in financial stability of municipal units, decrease in rates of economic growth of territories, but also decrease in satisfaction of the population the received services of the state, failure in political exchange "state - population" can become result of action of such trends.

\section{Discussion}

The results of the study are useful to consider from the point of view of the influence of fiscal decentralization on political exchange "state-population", which results in satisfaction of the population with power (loyalty) and improvement of the quality of life of the 
population. Due to the fact that in general, fiscal decentralization affects economic growth, and this indicator is included in the assessment of the quality of life of the population, this means that, together with other factors, fiscal decentralization contributes to political exchange, i.e. increases public satisfaction with the government. Even with a low level of fiscal decentralization, in the absence of a balance on revenues and expenditures at the municipal level, fiscal decentralization, affecting the quality of life, affects the efficiency of the state-population exchange, i.e. municipal finances become an economic basis not only for local self-government, but also for a positive political exchange. Consequently, the government of the federal and regional levels should be interested in the fiscal decentralization of municipalities. In our opinion, a decrease in fiscal decentralization in terms of expenditures at a constant level of fiscal decentralization in terms of income can lead to substantial political losses in the loyalty of the population.

However, with the current tax system of Russia and a certain agreement between the government and business on not increasing the tax burden, the search for ways to increase fiscal decentralization of revenues at the local level, in our opinion, can be done using new forms of financing, such as self-taxation of citizens, municipal loans, municipal and private partnership, initiative budgeting. It is important to notice that these new forms in many respects increase participation of citizens in the budgetary process and in social and economic development of municipalities.

Striking example in confirmation of this thesis is development of participatory or initiative budgeting which represents set of the various, based on citizens' initiative the practician according to the decision questions of local value with direct participation of citizens in definition and the choice of subjects to expenditure of budgetary funds and also in the subsequent control of implementation of the selected projects.

In 2006 the Government of the Russian Federation addressed the World Bank with the offer of development and realization in the territory of the country of the Community-based development programs. Since 2007 the Russian program which received the name «Local Initiatives Support Program» (LISP) started in municipal units in Stavropol Territory. Further practical involvement of citizens to the solution of questions of local value resulted in considerable positive results.

Successful implementation of the LISP promoted that the Agreement between the Ministry of Finance of the Russian Federation and the World Bank which purpose was a support, development and distribution of public participation in the budgetary process for 2016-2018 was concluded on April 7, 2016. With development of LISP financing of municipal projects considerably increased in municipal units of many Russian regions, the population began to be positive to implementation of projects as it notices improvement of infrastructure, and development of practice changes typology of initiatives in global scale. On the basis of it it is possible to draw a conclusion that citizens are located to such type of participation.

During 2016-2017 practice of initiative budgeting intensively developed. In 2016 in 35 territorial subjects of the Russian Federation 8732 projects of initiative budgeting were implemented. The number of projects increased in comparison with 2015 more than three times. The applications of initiative groups registered to participation (4237 in 2015 and 13531 in 2016) show a similar ratio. In terms of money the cost of the projects implemented in 2016 approached 7 billion rubles (in $2015-2.4$ billion rubles), Table 1.

Table 1. Dynamics of financing of projects of initiative budgeting in the Russian Federation in 20152016, million rubles. [15].

\begin{tabular}{|c|c|c|}
\hline \multicolumn{1}{|c|}{ Parameters } & $\mathbf{2 0 1 5}$ & $\mathbf{2 0 1 6}$ \\
\hline $\begin{array}{l}\text { Total cost of projects of initiative budgeting, } \\
\text { including: }\end{array}$ & 2394.98 & 6995.60 \\
\hline the volume of expenses on implementation of the & 1375.84 & 5132.60 \\
\hline
\end{tabular}




\begin{tabular}{|l|c|c|}
\hline $\begin{array}{l}\text { projects of initiative budgeting directed from } \\
\text { budgets of territorial subjects of the Russian } \\
\text { Federation }\end{array}$ & & \\
\hline $\begin{array}{l}\text { The total amount of joint financing from all sources, } \\
\text { including: }\end{array}$ & 1019.14 & 1863.00 \\
\hline $\begin{array}{l}\text { the volume of expenses on implementation of the } \\
\text { projects of initiative budgeting directed from the } \\
\text { federal budget }\end{array}$ & & 22.30 \\
\hline $\begin{array}{l}\text { the volume of expenses on implementation of the } \\
\text { projects of initiative budgeting directed from } \\
\text { budgets of municipalities }\end{array}$ & 614.91 & 1137.00 \\
\hline $\begin{array}{l}\text { the amount of funds of joint financing, the projects } \\
\text { of initiative budgeting involved on realization } \\
\text { from outside the population }\end{array}$ & 205.45 & 478.10 \\
\hline $\begin{array}{l}\text { the amount of funds of joint financing, the projects } \\
\text { of initiative budgeting involved on realization } \\
\text { from outside legal entities }\end{array}$ & 182.07 & 218.90 \\
\hline other forms of joint financing & 16.71 & 6.70 \\
\hline
\end{tabular}

Distinctive feature of projects of initiative budgeting is that in them joint financing mechanisms are actively used. Cumulative joint financing of projects from such sources as budgets of municipalities, means of citizens and business, apart from the centralized means, in 2018 almost doubled and exceeded 1.8 billion rub.

The typology of projects of initiative budgeting which reflects the main problems of citizens) is also of interest (Table 2).

Table 2. Typology of the main projects of initiative budgeting in 2016 [16].

\begin{tabular}{|c|l|c|c|}
\hline $\mathbf{N}$ o. & \multicolumn{1}{|c|}{ Types of projects of initiative budgeting } & $\begin{array}{c}\text { Number of } \\
\text { projects, } \\
\text { pieces }\end{array}$ & $\begin{array}{c}\text { Share of } \\
\text { projects on } \\
\text { types, \% }\end{array}$ \\
\hline 1 & $\begin{array}{l}\text { Places of mass rest of the population and objects of the } \\
\text { organization of improvement }\end{array}$ & 1673 & 18.1 \\
\hline 2 & Highways and constructions on them & 1344 & 14.5 \\
\hline 3 & Educational and cultural institutions & 1035 & 11.2 \\
\hline 4 & Subjects to water supply, water disposal & 1016 & 11.0 \\
\hline 5 & Arrangement of playgrounds & 819 & 8.8 \\
\hline 6 & Subjects to street lighting & 805 & 8.7 \\
\hline 7 & $\begin{array}{l}\text { Subjects to collecting solid municipal/household } \\
\text { waste and garbage }\end{array}$ & 491 & 5.3 \\
\hline 8 & Objects of physical culture and mass sport & 425 & 4.6 \\
\hline 9 & Event projects (holidays, festivals) & 425 & 4.6 \\
\hline 10 & Places of burial & 257 & 3.7 \\
\hline 11 & Objects for providing primary measures of fire safety & 191 & 2.8 \\
\hline 12 & Objects of cultural heritage (monuments, museums) & 47 & 2.1 \\
\hline 13 & Institutions of library service of the population & 19 & 0.5 \\
\hline 14 & $\begin{array}{l}\text { Objects for providing inhabitants with services of } \\
\text { consumer services }\end{array}$ & 372 & 4.2 \\
\hline 15 & $\begin{array}{l}\text { Other objects (repair of roads, bridges, dams, } \\
\text { improvement of reservoirs, organization of } \\
\text { communication, heat supply, sewerage, gas pipelines } \\
\text { and so forth) }\end{array}$ & & \\
\hline & In total projects & 9260 & $\mathrm{x}$ \\
\hline
\end{tabular}

Vagin V.V. and Sharapova N.A. summarize that the largest specific weight is the share of various projects of improvement [15, c 111]. 
As practice of realization of initiative budgeting showed, the most important element of its success is the efficiency of interaction of authorities with citizens and the organizations (business). In the Russian Federation such interaction is still undeveloped that creates certain problems [17]. On the one hand, authorities did not get used to interact with citizens and the organizations within implementation of the budgetary process as it imposes on them additional obligations. On the other hand, citizens do not know how to interact with officials or do not want to do it. he level of development of civil society in the Russian Federation the practician of public participation in the budgetary process does not allow to use fully opportunities and advantages.

The Ministry of Finance of the Russian Federation drew the closest attention to development of initiative budgeting from a position of increase in efficiency of use of budgetary funds and also to what is perceived by the population as priorities. Not less important the fact that initiative budgeting promotes strengthening of the mechanism of public control by means of decision-making with participation of citizens. In 2016 the Center of initiative budgeting at Research financial institution of the Ministry of Finance of the Russian Federation was created, and in 2016 the Agreement on implementation of the joint project of the World Bank and the Ministry of Finance of the Russian Federation on development of initiative budgeting in the Russian Federation is signed. It stimulated further growth of projects of initiative budgeting in Russia.

In 2017 the Program of development of initiative budgeting in the Russian Federation [18], in which the purpose and tasks, effects of initiative budgeting, development of its institutional infrastructure, mechanisms of implementation of the Program, monitoring of its performance are defined, was adopted and also the «road map» of development of initiative budgeting till 2022 was developed.

Results of development of initiative budgeting allow to distinguish it as one of the most successful examples of development of public participation in Russia for the last decade that, in our opinion, confirms increase in a role of local government in modern conditions. Implementation of the Program in practice showed that the involvement of citizens into the solution of issues of development of the territory improves interaction "state-population", political exchange becomes effective.

Search of ways of increase in initiative budgeting in income led us to a non-tax source of filling of municipal budgets popular at the moment. It is self-taxation of citizens. In 2017 the volume of self-taxation of citizens in regions grew by $12.4 \%$ concerning an indicator of 2016 and was 240.1 million rubles (in relation to 2013 the amount of funds of self-taxation grew by 9.3 times). The geography of introduction of self-taxation includes 36 regions. According to data of the Ministry of Finance of the Russian Federation, self-taxation of citizens was entered in 2017 in territories of 1,687 municipal units that makes $7.6 \%$ of total number of municipal units (in 201635 regions, 1,567 municipal units).

However authors consider self-taxation as an extraordinary source, and this thesis is confirmed by explanations of the Constitutional court of the Russian Federation which let know unambiguously that such financing from citizens belongs only to a last resort. If the self-taxation purposes regularly repeat, then it is the certificate of existing "failures" in work of the government.

Standard sources of financing are insufficient for financing of local investment requirements, and local governments often have no opportunities and resources for providing high-quality services alone. Interaction of the private sector through partnership with municipalities can become a part of the solution of this problem. Besides, the municipal-private partnership (MPP) offers the new opportunities for local investors inaccessible to them from large regional or federal projects.

The main incentive mechanisms for development of MPP from a position of business are [19]: 
- lack of the competition;

- high degree of security;

- status growth of business;

- the privileges provided by the law for such companies;

- desire to help the population, etc.

The MPP main directions are provided in Table 3 where it is possible to see that there is not a lot of such directions.

Table 3. Examples of the projects of municipal-private partnership implemented in Russia in 2016 [20].

\begin{tabular}{|l|l|}
\hline \multicolumn{1}{|c|}{ Field } & \multicolumn{1}{c|}{ Place } \\
\hline Cinema and recreation centers & $\begin{array}{l}\text { Arsenyev of Primorsky Krai (cinema) } \\
\text { Kirzhach (regional recreation center) } \\
\text { Novosibirsk (cinema) }\end{array}$ \\
\hline Objects of preschool education & Novosibirsk (municipal units of the Tomsk region) \\
\hline $\begin{array}{l}\text { Museums and objects of cultural } \\
\text { heritage }\end{array}$ & $\begin{array}{l}\text { Kaluga (memorial estate "Linen Plant") } \\
\text { Ulan-Ude (object of cultural heritage) }\end{array}$ \\
\hline Subjects to social service & $\begin{array}{l}\text { Novosibirsk, Cherepovets (bathhouse) } \\
\text { Kormilovka of the Omsk region (bathhouse) }\end{array}$ \\
\hline Objects of sport and tourism & $\begin{array}{l}\text { municipal units of the Nizhny Novgorod Region } \\
\text { Kovrov of the Vladimir region (swimingpool) }\end{array}$ \\
\hline Parks & $\begin{array}{l}\text { Sol-lletsk of the Orenburg region (park) } \\
\text { Orenburg (park) }\end{array}$ \\
\hline Objects of recycling & $\begin{array}{l}\text { Pasynkovo's natural boundary of the Vologda region } \\
\text { Alkeevsky municipal District of Republic of Tatarstan }\end{array}$ \\
\hline
\end{tabular}

The insignificant number of the MPP projects is explained, first of all, by complexity of interaction of business and municipalities.

The concession municipal bonds (CMB) issued on behalf of the municipal unit for financing of the concession project can become the additional channel of attraction of financial resources on local projects. CMB will allow to raise funds of citizens and business for reconstruction of objects of housing and public utilities, municipal roads, social objects, etc. However, today according to the conclusion of the National center of public-private partnership legal regulation of concession agreements and definition of their objects demands further regulation [21].

\section{Conclusions}

In the Russian Federation there is a gradual centralization of the budgetary system. This situation was aggravated with the facts that during 2014-2017 federal public authorities assigned to territorial subjects of the Russian Federation of power on execution of account obligations of municipalities, and that territorial subjects of the Russian Federation were forced to take away separate powers of municipal units as they had no financial opportunity to execute them. The result of such tendencies can be not only a deterioration in the financial stability of municipalities, a slowdown in the economic growth of the territories, but also a decrease in the population's satisfaction with the services provided by the state, which will lead to a "failure" in the political exchange «state-population». In these conditions search of the directions of increase in the fiscal decentralization can be carried out with use of new forms of financing, such as self-taxation of citizens, municipal loans, municipal-private partnership, initiative budgeting. It is important to notice that these new forms strongly increase participation of citizens in the budgetary process and in social and economic development of municipalities. 


\section{References}

1. T. Garcia-Mila, T. J. McGuire, W. E. Oates, International tax and public finance 25(4), 1071-1091 (2018) DOI: 10.1007/s10797-018-9485-4

2. H. Zimmermann, Journal Of Economic Geography 4, 473-474 (2004) DOI: 10.1093/jnlecg/lbh022

3. H. Davoodi, H. Zou, Journal of Urban Economics 43(2), 244-257 (1998) DOI: 10.1006/juec.1997.2042

4. L. Freinkman, K.A. Kholodilin, , U. Thiessen, DIW Berlin Discussion, 912 (2009) https://ssrn.com/abstract $=1493158$ or http://dx.doi.org/10.2139/ssrn.1493158

5. N. Gemmell, R. Kneller, D. McGowan, I. Sanz, J.F. Sanz-Sanz, Evidence from European Firms (2013) https://ssrn.com/abstract=2256750 or http://dx.doi.org/10.2139/ssrn.2256750

6. V. N. Yuzhakov, E. I. Dobrolyubova, A. N. Pokida, N. V. Zybunovskaya, Ekonomicheskaya Politika (2019) DOI: 10.18288/1994-5124-2019-1-92-115

7. A. O. Yushkov, N. Y. Oding, L. I. Savulkin, Issues of Economics 12, 46-65 (2018) https://doi.org/10.32609/0042-8736-2018-12-46-65

8. N. M. Sabitova, M.R. Shagiahmetov, N.G. Ivanova, International Business Management $\quad \mathbf{1 0 ( 2 2 ) ,} \quad 5243-5247 \quad$ (2016) https://www.scopus.com/authid/detail.uri?authorId=56969092200

9. V. A. Fedosov, Public participation in the budgetary process: foreign experience and Russian practice, 143 https://elibrary.ru/download/elibrary_30027705_49961068.pdf

(2017)

10. G. Morunova, S. Gorbushina, V. Okrepilov, S. Kuzmina, MATEC Web of Conferences 239, 08005 (2018) https://doi.org/10.1051/matecconf/201823908005

11. G.V. Morunova, The theory, the legislation and practice of the organization of municipal finance in transformational economy (Publishing house of Saint Petersburg State University of Economics, SPb, 2016) https://elibrary.ru/download/elibrary_29395132_33550240.pdf

12. A. Chernikova, S. Golovkina, S. Kuzmina, T. Demenchenok, IOP Conference Series: $\begin{array}{lllll}\text { Earth and } & \text { Environmental } & \text { Science } & \end{array}$ https://doi.org/10.1051/e3sconf/20199105007

13. A.M. Lavrov, E.A. Dombrovsky, Finance 5, 21 https://nifi.ru/images/FILES/Journal/Archive/2017/6/fm_2017_6.pdf

14. Russian Federation: Federal law of 6.10.2003 No. 131-FZ

15. V.V. Vagin, $\quad$ FM $1, \quad 110-122$ http://www.nifi.ru/images/FILES/Journal/Archive/2018/1/statii 2018_1/fm 2018_1 09.pdf

16. I.E. Shulga, V.V. Vagin, G.N. Hachatryan, A.S. Sukhova, L.A. Shilov, N.V. Gavrilova, N.A. Shapovalova, Initiative budgeting. The Russian experience in the field of participation of citizens in the solution of questions of local value (Alex, Moscow, 2017)

17. I.E. Shulga, V.V. Vagin, Developing Participatory Budgeting in Russia, Hope For Democracy. 30 Years of Participatory Budgeting Worldwide (Faro, Portugal) https://www.oficina.org.pt/hopefordemocracy.html

18. https://ppp.worldbank.org/public-private-partnership/ppp-health 
19. Materials of an expert session. Mechanisms of public-private partnership, municipal and private partnership in the Russian Federation: definition, statistics, forms, economy, practice and prospects of application (2016) http://www.investr.ru/files/blocksgallery/tkachenko_m_v_ekspertnaya_sessiya_mehani zmi_gchp_mchp_v_rf.pdf

20. http://pppcenter.ru/assets/files/reliz-1511018.pdf (Last accessed 11.11.2018) 